\title{
がん悪液質におけるインスリン抵抗性の関与
}

\author{
大澤匡弘, * 村上友康, 夈 和彦
}

\section{Possible Involvement of Insulin Resistance in the Progression of Cancer Cachexia in Mice}

\author{
Masahiro Ohsawa, ${ }^{*}$ Tomoyasu Murakami, and Kazuhiko Kume \\ Department of Neuropharmacology, Graduate School of Pharmaceutical Sciences, \\ Nagoya City University; 3-1 Tanabe-dori, Mizuho-ku, Nagoya 467-8603, Japan.
}

(Received September 18, 2015)

\begin{abstract}
Malnutrition is a common problem among cancer patients, affecting up to $85 \%$ of patients with certain cancers. In severe cases, malnutrition can progress to cachexia, a specific form of malnutrition characterized by loss of lean body mass and muscle wasting. Although this muscle wasting might be a product of enhanced protein degradation, the precise mechanisms of cancer cachexia are not fully elucidated. Based on basic and clinical research, glucose intolerance and insulin resistance have been postulated to be associated with cancer cachexia. Since insulin in the skeletal muscle inhibits protein degradation and promotes protein synthesis, insulin resistance could be a possible cause of cancer cachexia. Therefore, we investigated the involvement of insulin resistance in the development of cancer cachexia in tumor-bearing mice. The signaling protein in the insulin cascade was attenuated in the skeletal muscle and hypothalamus from tumorbearing mice. We identified Chrysanthemum morifolium RAMAT., known as Kikuka, as a peroxisome proliferator-activated receptor $\gamma(\operatorname{PPAR} \gamma)$ ligand. Treatment with Kikuka attenuates the skeletal muscle changes in tumor-bearing mice. These results suggest that this natural PPAR $\gamma$ activator might be an attractive candidate for the treatment of cancer cachexia. In the symposium, we presented the $\operatorname{PPAR} \gamma$ activator-induced improvement of cancer cachexia.
\end{abstract}

Key words_- cancer cachexia; insulin resistance; sarcopenia; Kikuka (Chrysanthemum morifolium RAMAT.); peroxisome proliferator-activated receptor $\gamma$

\section{悪液質とは}

悪液質は，栄養不良により衰弱した状態を指す言 葉として用いられてきたが，長年，明確な定義がな く, あいまいな概念であった。 2006 年, 米国ワシ ントンで開催されたコンセンサス会議において, 「悪液質は基礎疾患に関連して生ずる複合的代謝異 常の症候群で, 脂肪量の減少の有無にかかわらず筋 肉量の減少を特徵とする。臨床症状として成人では 体重減少，小巟では成長障害がみられる」と定義さ れた。 2011 年初めには, がん悪液質について,「従 来の栄養サポートにより改善することが困難であ り，さらに進行性の機能障害を引き起こす（脂肪組 織の減少の有無にかかわらず) 著しい筋組織の減少 を特徵とする複合的な疾患群を指す。病態生理学的

名古屋市立大学大学院薬学研究科神経薬理学分野 ( ( $467-8603$ 名古屋市瑞穂区田辺通 3-1)

*e-mail: ohsawa@phar.nagoya-cu.ac.jp

本総説は, 日本薬学会第 135 年会シンポジウムS34 で 発表した内容を中心に記述したものである.
には，経口摂取の減少と代謝異常によるタンパクと エネルギー平衡の破綻を特徵とする」と定義され た.これは, European Palliative Care Research Collaborative (EPCRC) や European Association for Palliative Care (EAPC), European Society for Clinical Nutrition and Metabolism (ESPEN) と いつた欧州における緩和・栄養関連の主要学会並び に北米のエキスパートによって支持されており，現 在のところがん悪液質の標準的な定義とされている ものの, 今後の研究によっては変更を余儀なくされ ることもあるのではないかと思われる.

悪液質は，がんのほかに腎不全や心不全，慢性閉 塞性肺疾患 (chronic obstructive pulmonary disease; COPD), 感染症などの慢性的な消耗性疾患の悪化 に伴って出現する. 末期がん患者では，大多数に悪 液質がみられ, 生活の質の低下や生存期間の短縮, 積極的がん治療の中止，がん治療に対する反応性の 低下など, 数多くの悪影響を与える. 例えば, 悪液 質はがんの死因の約 30\%を占めていると言われて 


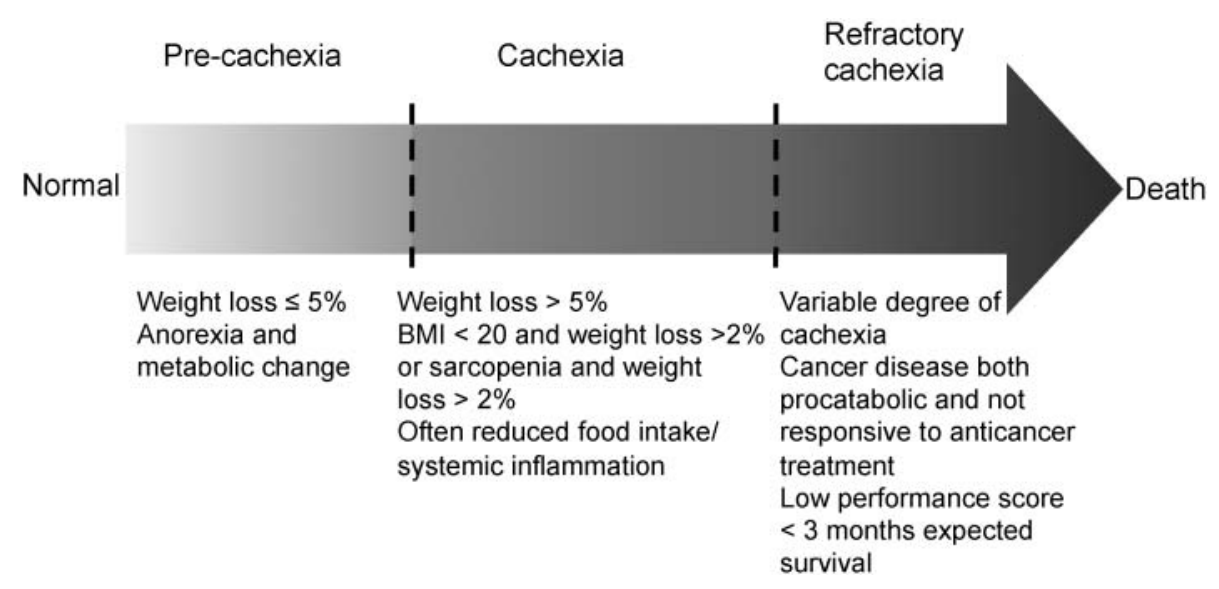

Fig. 1. Stages of Cancer Cachexia

Cachexia is defined into three stages depending on the patients' status. Pre-cachexia showed anorexia and metabolic changes without the substantial involuntary body weight loss. Refractory cachexia is clinically refractory as a result of very advanced cancer or the presence of rapidly progressive cancer unresponsive to anticancer therapy. Cachexia is the condition between pre-cachexia and refractory cachexia. Modified from Ref. 7).

いる. ${ }^{1-3)}$ 生命の維持に不可欠な骨格筋が可及的に 温存され, 脂肪組織が優先的に減少する飢餓による 低栄養状態とは対照的で，悪液質では早期から骨格 筋量が減少する. ${ }^{4)}$

がん悪液質を生じ難いがん種もあり，その進行速 度も様々であるが, がん悪液質はがんの進行ととも に次第に死をもたらす不可逆性の栄養不良へと進展 する．がん悪液質がもたらす栄養不良は食欲不振が 大きく影響するものの，根本的には全身の慢性炎症 反応による代謝異常であるため, 骨格筋組織の分解 克進やインスリン抵抗性, 脂質分解の充進等の異化 克進がみられる。この代謝障害が高度になると，栄 養不良は不可逆的となる。がん悪液質が軽度な状態 は “pre-cachexia”と呼ばれ，この段階で栄養状態 の悪化を可及的に遅らせることが重要である. ${ }^{2,5)}$ ま た, “late cachexia”, “severe cachexia”などの呼称 が用いられてきた高度代謝障害により栄養状態の改 善の余地がない最終末期の状態は, EPCRCのガイ ドラインでは “refractory cachexia”とされた (Fig. 1).このガイドラインの中で cachexia の前後 にある pre-cachexia と refractory cachexia のステー ジ概念は，がん患者の栄養管理を行う上で大きな意 味があるだけでなく, 薬物治療が介入すべきポイン トを見定める上でも重要である. ${ }^{6}$

悪液質の進行を阻止する効果的な治療法はいまだ 見い出されていない. 悪液質の発症メカニズムはな かなか解明が進まず，代謝栄養学的見地から食欲不 振による栄養摂取量の低下とエネルギー消費の増大
が要因と考えられるにすぎなかった。しかし，がん 悪液質患者に高カロリー輸液などの十分な栄養投与 を行ってもがん悪液質を改善できないことから，近 年, 腫瘍の発育・進展に伴って, 腫瘍やその存在に 対する反応として患者組織から分泌・遊離される種 々の因子が，栄養障害の発現に係わつていると考え

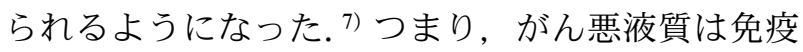
や代謝, 神経内分泌系の異常が複雑に絡み合つて誘 発される病態と言える，そのため，がん悪液質に係 わる炎症性サイトカイン類や腫瘍由来因子に加え, 脂肪, 筋肉などの機能を維持する分子レベルでの検 討が勢力的に行われている.このようながん悪液質 の病態に関する分子レベルの理解は, 新しい治療標 的の発見と治療法の開発に結びつくと期待できる.

\section{がん悪液質とインスリン抵抗性の関係}

がん悪液質患者では，1919年という古くから耐 糖能異常が認められることが知られていた。 ${ }^{8)}$ た，動物実験においても，インスリンによる血糖降 下作用が担がん動物において有意に減弱しているこ

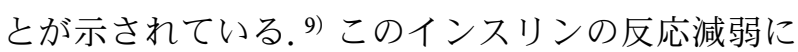
は，インスリン抵抗性が係わっていると考えられ， 肝臓や骨格筋においてインスリン抵抗性が生じてい ることも明らかにされている。 また，インスリン抵 抗性に関与すると考えられている全身の脂質分解も がん悪液質では充進しており, 脂質代謝の克進によ りインスリン抵抗性が生じてがん悪液質が発現する と考えられている，実際に，脂肪細胞内に貯蔵され た脂質を分解する酵素である脂肪トリグリセリドリ 
パーゼ (adipose triglyceride lipase; ATGL) が, が ん悪液質の発現には重要であると, 遺伝子操作によ り ATGL を欠損させた動物を用いた研究より明ら かにされている. ${ }^{10)}$

インスリン抵抗性を改善する peroxisome proliferator-activated receptor $\gamma(\operatorname{PPAR} \gamma)$ 活性化 薬のロシグリタゾンは，がん悪液質モデルマウスの 体重量と脂肪組織量の減少を軽減する. ${ }^{9)}$ また， 口 シグリタゾンの投与により，がん悪液質モデルマウ スでみられるインスリン抵抗性が改善し，アディポ ネクチン量も上昇することが示されている。ささ に，がん悪液質モデルマウスの骨格筋におけるタン パク分解に関与する Atrogin-1 や muscle RING-finger protein-1（MuRF-1）遺伝子発現の上昇もロシ グリタゾンにより抑制されることから，タンパク分 解の亢進も改善すると考えられる。加えて，骨格筋 のタンパク合成に係わる細胞内情報伝達系であるイ ンスリンシグナル分子の活性も，がん悪液質モデル マウスでは低下していることから，タンパク合成系 の機能低下もがん悪液質の発現に係わっていると言 える. インスリンの投与によっても，筋肉量の増加 や脂肪組織の増加, 安静時のエネルギー消費量の低

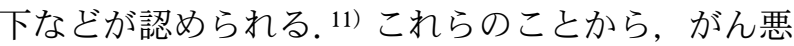
液質に対してインスリン受容体の感受性改善薬やイ ンスリンの投与が治療効果を持つものと期待されて いる．インスリンはがん細胞の増殖に係わる因子で あるが，がん悪液質の状態にインスリンを使用して もがんの進行は認められないと報告されている. ${ }^{10)}$

\section{悪液質の動物モデル}

がん悪液質の動物モデルとして，がん細胞をマウ スやラットに移植する方法が一般的に用いられる.

特に, Lewis lung carcinoma (LLC) ${ }^{12-17)}$ や colorectal tumors, ${ }^{18-20)}$ syngenic sarcomas ${ }^{13,21-25)}$ は，よく用 いられる細胞株である。これらの細胞株を皮下に移 植すると，ヒトの悪性新生物のような転移はみられ ないものの，宿主とがん細胞の相互作用を引き起こ し，炎症性サイトカイン類やプロスタグランジン類 の産生をさせ，ヒトにみられる悪液質と同様の症状 が出現するため，これら細胞株を皮下に移植した動 物モデルは，ヒトのがん悪液質を模倣するモデルと して使用されている。

これらの細胞株のほかに，メラノーマ細胞も悪液 質を引き起こす. ${ }^{10,26)}$ 筆者らも，メラノーマ細胞を
側腹部皮下に移植して，移植後 18 日目の骨格筋重 量や腫瘍を除いた体重量が，対照群マウスと比べ有 意に低下していることを確認した。一方，メラノー マ細胞の移植により腫瘍の形成が認められる移植 10 日後では，骨格筋重量や腫瘍を除いた体重量に 対照群マウスと比較して変化はみられなかつた。臨 床におけるがん悪液質の定義に当てはめると，メラ ノーマ移植 10 日後が pre-cachexia 状態であり, 18 日後が cachexia 状態であると考えられた.

\section{悪液質モデルにおけるインスリンシグナリングの} 変化

$\operatorname{PPAR} \gamma$ 活性化薬ががん細胞移植による悪液質モ デルの症状を改善したことから，悪液質モデルでは インスリン抵抗性が生じていることが考えられる. そこで，骨格筋組織である腓腹筋におけるインスリ ンシグナルや，それに影響を与える分子の発現につ いて解析を行った。メラノーマ細胞移植 18 日目の 腓腹筋では，インスリンシグナル分子である Akt のリン酸化が有意に低下しており, サイトカインシ グナル分子であり，インスリンの細胞内情報伝達系 を抑制する signal tranducer and activator of transcription 3 （STAT3）のリン酸化は有意に上昇して いた。 一方，メラノーマ細胞移植 10 日目の腓腹筋 では Akt のリン酸化に変化は認められなかったも のの，サイトカインシグナルの下流にある STAT3 のリン酸化は上昇していた。また，骨格筋のタンパ ク質量を反映するミオシン重鎖の発現は，メラノー マ細胞移植 10 日目では明らかな変化は認められな かったものの，移植 18 日目においては，著しい低 下が認められた。さらに，筋肉増殖の負の制御因子 として機能している Myostatin の発現も，ミオシン 重鎖と同様にメラノーマ移植後 10 日目では変化が 認められず，18 日目では有意に増加していた。こ れらのことから，メラノーマ移植マウスでは，骨格 筋におけるインスリンシグナルの減弱が起こってお り，骨格筋の萎縮が生じていることが明らかになつ た。 また，白色脂肪組織におけるタンパク質発現に ついても解析を行い，メラノーマ移植後 10 日目に おいて, STAT3 のリン酸化とAkt のリン酸化の上 昇が認められた。 Akt は脂肪細胞において脂質合成 を促進し，脂肪細胞のサイズを大きくし， STAT3 は脂肪細胞の性質を変化させ，インスリン抵抗性を 促進する因子を放出させることが知られている。こ 


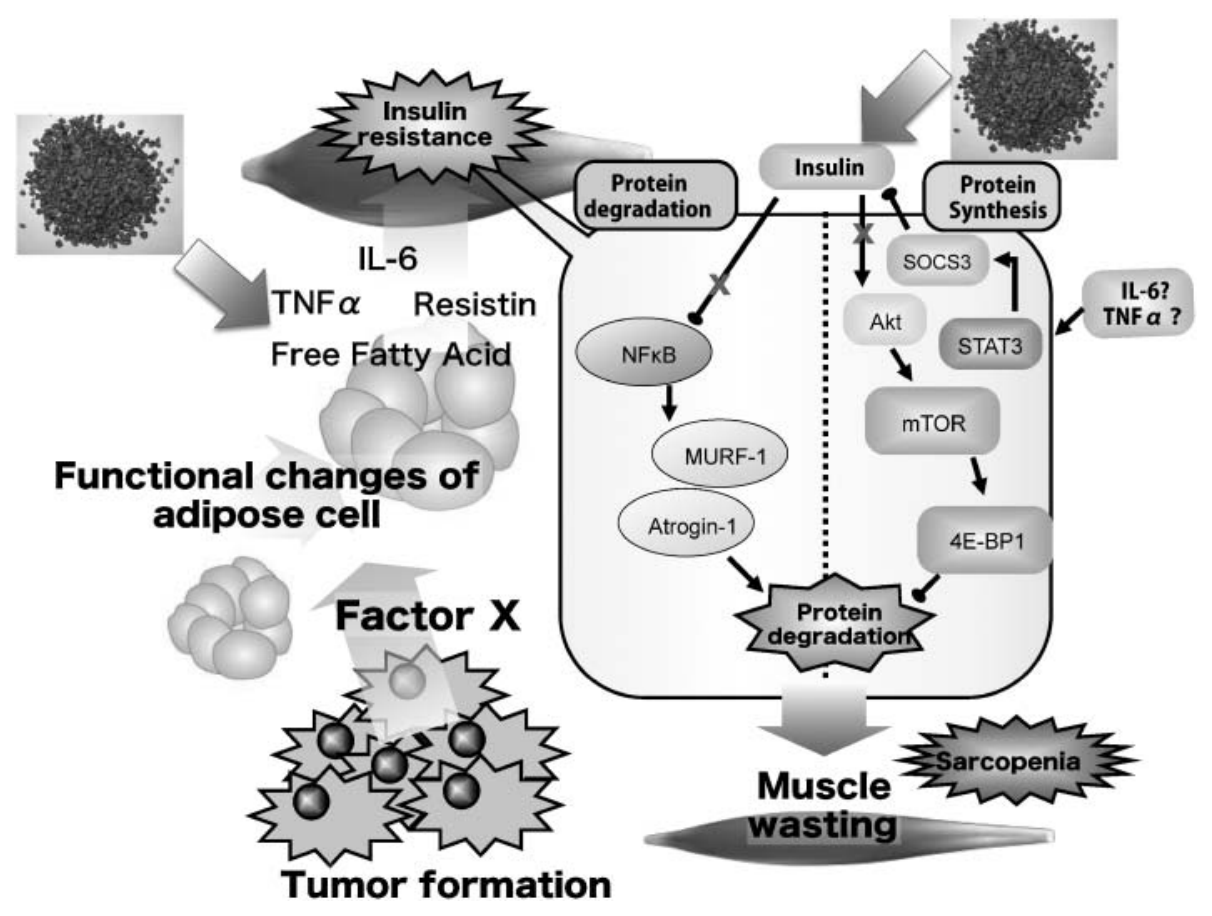

Fig. 2. Schematic Representation of the Effect of Kikuka (Chrysanthemum morifolium RAmAT.) on the Melanoma-induced Cancer Cachexia in Mice

Details are provided in the text. In brief, insulin resistance in cancer cachexia mouse skeletal muscle is caused by the increase of inflammatory cytokines, tumornecrosis factor- $\alpha$, free fatty acids which is released from adipocytes. Kikuka improves the insulin receptor function through the activation of PPAR $\gamma$ in the skeletal muscle and adipose tissue.

の白色脂肪細胞の性質変化は，2 型糖尿病と同様の 変化であり，がん悪液質モデルマウスの脂肪組織に おいても，インスリン抵抗性が白色脂肪細胞の機能 変化を起点として, pre-cachexia 状態から認められ ることが明らかになった。 なお，メラノーマ移植後 18 日目においては, 脂肪組織が消失しており, 夕 ンパク質発現についての検討を行うことはできな かった。褐色脂肪組織においては，メラノーマ移植 後 5 日目において体温産生並びにミトコンドリアに おけるエネルギー産生に関与する uncoupling protein 1 (UCP1) の mRNA 発現や, UCP1 の発現を 誘導する peroxisome proliferator-activated receptor gamma, coactivator $1 \alpha$ (PGC-1a) の mRNA の発現 が上昇していた。このことから，メラノーマを移植 されたマウスでは，悪液質の症状が出現するよりは るか前に全身の異化反応が活発化し，全身のエネル ギー消費が充進していることが明らかになった。

\section{悪液質を改善する生薬成分の探索}

がん性悪液質の進行は，PPAR $\gamma$ アゴニストによ り緩徐になることが示されたことから，PPAR $\gamma$ ア ゴニスト活性のある生薬であるキクカ（Chrysanthemum morifolium RAMAT.) ${ }^{27)}$ のがん悪液質に対
する効果を検討した。 キクカは, 解熱, 解毒, 鎮 痛，消炎作用を有しており，感冒や発熱，悪寒，頭 痛の際に頻繁に用いられる，漢方薬としては，釣藤 散の中に含まれており，有効成分として luteolin が 知られている.

まず，キクカを含む飼料をメラノーマ移植マウス に与えたところ, 体重量の減少が改善した。 また, 腓腹筋の重量低下もキクカにより改善した。一方, 腫瘍重量に対し，キクカは有意な影響を与えなかつ たことから，腫瘍の肥大には影響を与えず，悪液質 の症状を改善することが示唆された。また，メラ ノーマ移植マウスでみられた腓腹筋におけるリン酸 化 Akt 量の低下やリン酸化 STAT3 量の上昇を改善 した。 さらに，メラノーマ移植マウスの白色脂肪組 織で認められたリン酸化 STAT3 の上昇並びにリン 酸化 Akt の上昇も，キクカにより抑制された。こ れらのことから，キクカはメラノーマ移植により生 じた骨格筋や脂肪組織におけるインスリンシグナル の変化を正常化することが明らかになり，メラノー マ移植による悪液質の症状も緩徐にすることが示さ れた。 
まとめ

がん悪液質の発症メカニズムについては不明な点 が多い。今回，インスリン抵抗性が悪液質の発症に 係わることを明らかにし，想定されるメカニズムを Fig. 2 に示した. がん細胞の増殖に伴い，なんらか の因子（Fig. 2 では，因子 X) が放出され，白色脂 肪組織の機能变化と白色脂肪組織への炎症細胞浸潤 を引き起こす。その結果, 脂肪細胞の機能が変化し インスリン抵抗性を引き起こす因子のインターロイ キン-6 や腫瘍壊死因子 $\alpha$, 遊離脂肪酸などを放出 し，骨格筋の STAT3 シグナルを活性化する. STAT3 シグナルは，インスリンシグナルを抑制 し，リン酸化 Akt を阻害する。インスリンシグナ ルは, タンパク質合成系を促進し，分解系の機能を 抑制することから，悪液質状態では骨格筋のタンパ ク質分解系の克進が示唆される。このタンパク質分 解系の克進により，筋肉の委縮が生じ，結果として 悪液質となったと考えられる（Fig. 2).

一方, PPAR $\gamma$ 活性化因子であるロシグリタゾン やキクカは, 脂肪細胞の機能変化を抑制すること, 並びに骨格筋のインスリン感受性を改善すること で，悪液質の進行を緩徐にすることが示唆された。 今後, キクカの有効成分を同定することで, 治療が 不可能であった悪液質の症状を緩和することが可能 になるものと期待される.

謝辞本研究を行うに当たり, 生薬のメタノー ル抽出液を提供頂いた牧野利明先生（名古屋市立大 学大学院薬学研究科) 並びにルシフェラーゼアッセ イに必要なべクターを作製頂いた杉山晶則先生（岩 手医科大学薬学部）に感謝いたします。また，本研 究の一部は, 独立行政法人科学技術振興機構研究成 果展開事業研究成果最適展開支援プログラム（シー ズ顕在化タイプ）「骨格筋量を維持・増加させる生 薬「キクカ」の有効成分の探索」並びにがん研究開 発費 23-A-2 (特)「基礎と臨床の橋渡しのための研 究」の支援により行った.

利益相反＼cjkstart開示すべき利益相反はない.

\section{REFERENCES}

1) Acharyya S., Butchbach M. E., Sahenk Z., Wang H., Saji M., Carathers M., Ringel M.
D., Skipworth R. J., Fearon K. C., Hollingsworth M. A., Muscarella P., Burghes A. H., Rafael-Fortney J. A., Guttridge D. C., Cancer Cell, 8, 421-432 (2005).

2) Fearon K. C., Eur. J. Cancer, 44, 1124-1132 (2008).

3) Tisdale M. J., Physiol. Rev., 89, 381-410 (2009) .

4) Brennan M. F., Cancer Res., 37, 2359-2364 (1977).

5) Muscaritoli M., Anker S. D., Argilés J., Aversa Z., Bauer J. M., Biolo G., Boirie Y., Bosaeus I., Cederholm T., Costelli P., Fearon K. C., Laviano A., Maggio M., Rossi Fanelli F., Schneider S. M., Schols A., Sieber C. C., Clin. Nutr., 29, 154-159 (2010) .

6) Fearon K., Strasser F., Anker S. D., Bosaeus I., Bruera E., Fainsinger R. L., Jatoi A., Loprinzi C., MacDonald N., Mantovani G., Davis M., Muscaritoli M., Ottery F., Radbruch L., Ravasco P., Walsh D., Wilcock A., Kaasa S., Baracos V. E., Lancet Oncol., 12, 489-495 (2011).

7) Fearon K., Strasser F., Anker S. D., Bosaeus I., Bruera E., Fainsinger R. L., Jatoi A., Loprinzi C., MacDonald N., Mantovani G., Davis M., Muscaritoli M., Ottery F., Radbruch L., Ravasco P., Walsh D., Wilcock A., Kaasa S., Baracos V. E., Lancet Oncol., 12, 489-495 (2011).

8) Rohdenburg G. L., Bernhard A., Krehbiel O., J. Am. Med. Assoc., 72, 1528-1530 (1919) .

9) Asp M. L., Tian M., Wendel A. A., Belury M. A., Int. J. Cancer, 126, 756-763 (2010) .

10) Das S. K., Eder S., Schauer S., Diwoky C., Temmel H., Guertl B., Gorkiewicz G., Tamilarasan K. P., Kumari P., Trauner M., Zimmermann R., Vesely P., Haemmerle G., Zechner R., Hoefler G., Science, 333, 233-238 (2011).

11) Lundholm K., Körner U., Gunnebo L., SixtAmmilon P., Fouladiun M., Daneryd P., Bosaeus I., Clin. Cancer Res., 13, 2699-2706 (2007) .

12) Marks D. L., Butler A. A., Turner R., Brookhart G., Cone R. D., Endocrinology, 144, 1513-1523 (2003).

13) Marks D. L., Ling N., Cone R. D., Cancer Res., 61, 1432-1438 (2001). 
14) Markison S., Foster A. C., Chen C., Brookhart G. B., Hesse A., Hoare S. R., Fleck B. A., Brown B. T., Marks D. L., Endocrinology, 146, 2766-2773 (2005).

15) Nicholson J. R., Kohler G., Schaerer F., Senn C., Weyermann P., Hofbauer K. G., J. Pharmacol. Exp. Ther., 317, 771-777 (2006).

16) Jiang W., Tucci F. C., Tran J. A., Fleck B. A., Wen J., Markison S., Marinkovic D., Chen C. W., Arellano M., Hoare S. R., Johns M., Foster A. C., Saunders J., Chen C., Bioorg. Med. Chem. Lett., 17, 5610-5613 (2007).

17) Tran J. A., Jiang W., Tucci F. C., Fleck B. A., Wen J., Sai Y., Madan A., Chen T. K., Markison S., Foster A. C., Hoare S. R., Marks D., Harman J., Chen C. W., Arellano M., Marinkovic D., Bozigian H., Saunders J., Chen C., J. Med. Chem., 50, 6356-6366 (2007).

18) Joppa M. A., Gogas K. R., Foster A. C., Markison S., Peptides, 28, 636-642 (2007).

19) Vos T. J., Caracoti A., Che J. L., Dai M., Farrer C. A., Forsyth N. E., Drabic S. V., Horlick R. A., Lamppu D., Yowe D. L., Balani S., Li P., Zeng H., Joseph I. B., Rodriguez L. E., Maguire M. P., Patane M. A., Claiborne C. F., J. Med. Chem., 47, 16021604 (2004).
20) Weyermann P., Dallmann R., Magyar J., Anklin C., Hufschmid M., Dubach-Powell J., Courdier-Fruh I., Henneböhle M., Nordhoff S., Mondadori C., PLoS One, 4, e4774 (2009).

21) DeBoer M. D., Zhu X. X., Levasseur P., Meguid M. M., Suzuki S., Inui A., Taylor J. E., Halem H. A., Dong J. Z., Datta R., Culler M. D., Marks D. L., Endocrinology, 148, 3004-3012 (2007).

22) Ramos E. J., Middleton F. A., Laviano A., Sato T., Romanova I., Das U. N., Chen C., Qi Y., Meguid M. M., J. Am. Coll. Surg., 199, 716-723 (2004).

23) Wang Z., Wang W., Qiu W., Fan Y., Zhao J., Wang Y., Zheng Q., Acta Biochim. Biophys. Sin. (Shanghai), 39, 992-998 (2007).

24) Ramos E. J., Romanova I. V., Suzuki S., Chen C., Ugrumov M. V., Sato T., Goncalves C. G., Meguid M. M., Brain Res., 1046, 157164 (2005).

25) Goncalves C. G., Ramos E. J., Romanova I. V., Suzuki S., Chen C., Meguid M. M., Surgery, 139, 202-208 (2006).

26) Graves E., Ramsay E., McCarthy D. O., Res. Nurs. Health, 29, 87-97 (2006).

27) Yokoi H., Mizukami H., Nagatsu A., Ohno T., Tanabe H., Inoue M., Biol. Pharm. Bull., 32, 735-740 (2009). 